\title{
Impact Of Country Financial Development On The Firm: International Evidence
}

\author{
Ahmet Can Inci, (E-mail: acinci@sabanciuniv.edu), Sabanci University, Turkey
}

\begin{abstract}
The impact of financial development of a country on the earnings, capital spending, and stock returns of the firms of that country is the subject of this study. There are two different financial development indices which are utilized. The first is based on Love (2003), and the second is based on Khurana (2006). Using 40 different countries, the causality relationships and cumulative impacts of the lags of earnings and lags of capital spending on subsequent earnings, capital spending, and returns are examined for the financially developed countries and financially nondeveloped countries. Earnings and capital spending Granger-cause stock returns in financially developed countries. There is also evidence of efficiency in financially developed countries.
\end{abstract}

Keywords: Financial development, Earnings, Capital spending, Stock returns

\section{Introduction}

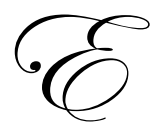

arnings generated by the firm impact stock returns from two different perspectives. The direct impact is because dividends are paid out of earnings. In standard financial models, the value of a stock depends on future dividends; therefore an increase in earnings leads to an increase in future dividends, and the stock price changes accordingly. The indirect impact is because of the portion of the earnings kept within the firm and used for investment purposes. These investments will eventually generate more earnings, which in turn will lead to bigger dividends and higher stock returns.

The fraction of the earnings that is distributed as dividends and the remaining fraction used for investments is a managerial decision. This decision also depends on the level of financial development of a country. In financially developed countries, a firm can easily access outside cash through the well-functioning financial markets of the country. This can be through seasoned equity offerings, preferred stock, or by issuing corporate bonds, among other possibilities. But if the markets are non-financially developed, then the portion of the earnings kept in the company will be larger. Therefore, the impact of the level of financial development in a country on the causality relationships between earnings, capital expenditure, and stock returns is the main focus of this study.

Prior research has posited that market imperfections and the lack of institutions which protect investor interests create a divergence between the cost of internal and external funds. This constrains firms' ability to fund investment projects through external financing. One consequence of financial constraints is that it forces firms to manage their cash flows to finance potentially profitable projects. A related stream of research documents that financial constraints due to costly external financing are more pronounced in underdeveloped financial markets.

Khurana et al. (2006) examine the influence of financial development on the demand for liquidity by focusing on how financial development affects the sensitivity of firms' cash holdings to their cash flows. They find that the sensitivity of cash holdings to cash flows decreases with financial development. A related important question pursued in the finance and economics literature is whether financial development positively contributes to economic growth (Gomes, 2002). A theoretical view underlying this line of inquiry is that financial development improves firms' access to lower cost external financing. Rajan and Zingales (1998) argue that well developed "financial markets and institutions help a firm overcome problems of moral hazard and adverse selection, thus reducing the firm's cost of raising money from outsiders." In contrast, these problems are exacerbated in less 
financially developed countries, thereby creating a wider wedge between firms' internal and external cost of funds (La Porta et al. 1997). Consequently, theory anticipates firms in these countries to be financially constrained in that firm investments (and in turn firm growth) are more likely to be limited to available internal resources. Extant research provides several pieces of evidence consistent with this prediction. For example, Rajan and Zingales (1998) find that industries that are reliant on external financing exhibit greater growth in financially developed countries. Similarly, Demirguc-Kunt and Maksimovic (1998) find that firm growth financed by long-term external debt and equity is positively associated with the level of a country's financial development. More recently, Love (2003) finds that financial development affects firm investments through its impact on firms' cost of capital. Her results also support the view that financing constraints decrease with financial market development.

The objective of this paper is to examine the impact of financial market development on the causality relationships between earnings, capital spending and stock returns. The study reveals that for the non-financial group of countries, earnings do not impact stock returns. Capital spending does not impact future returns either jointly or cumulatively. For the financially developed group, both earnings and capital spending impact stock returns. Financially developed countries make it easy for firms to get external financing and capital spending in these countries, whether originating externally or internally, influences stock returns significantly. Furthermore, earnings in financially developed countries also lead to significant stock returns. It seems that well-functioning financial markets also bring in the monitoring mechanisms and the corporate governance structure. The managers in financially developed countries use earnings and capital spending on better projects and investments. We do not see these results in financially non-developed countries.

From capital investment to earnings, there is weak evidence of Granger-causality in financially undeveloped countries; however, the cumulative effect reduces earnings. This is an indication that in undeveloped countries, investment decisions of managers are not always correct and may lead to declines in earnings. Furthermore, the managers of firms in financially undeveloped countries may not be monitored effectively. There do not seem to be useful and preventive corporate governance mechanisms. Independent auditors as well as company and stock analysts may not have the means to observe managers' talents and force them to make good managerial decisions.

In financially developed countries, on the other hand, there is not strong evidence of capital investment Granger-causing earnings (Partially this is because impact of capital spending to earnings is prompt; in other words, earnings increase is contemporaneous indicating efficiency in these economies). The cumulative effect, on the other hand is positive (though not very significant). In other words, capital investment does lead to increased earnings since the point estimates are positive. In financially developed countries, external financing is cheap and easy to obtain (Rajan and Zingales, 1998). Managers may prefer external funding and they are not faced with financing constraints but still use these funds effectively. As a result, capital investment, which originates from internal resources, has comparatively more significant causality effect on earnings.

From earnings to capital spending there is clear evidence that earnings Granger cause capital investment. Earnings have a cumulative impact of increasing capital investment as well. There does not seem to be a difference in this regard between financially developed and undeveloped countries. And the results are consistent both for the Love (2003) financial development index classification and for the Khurana et al. (2006) index classification.

The rest of the article is organized as follows. Section 2 describes the data and empirical methodology. Section 3 presents the discussion of the results. Section 4 is the conclusion. 


\section{Data And Empirical Methodology}

\subsection{Data Construction}

The data of the study are from the Worldscope database. Annual earnings, capital spending, and stock returns of individual firms from 40 different countries from 1990 through 2004 are used. The earnings and capital spending are normalized with assets. This helps achieve stationarity for these variables and eliminates the need to use co-integration, normalize the variables using inflation rates, or take care of size effects ${ }^{1}$.

When the samples are created for each country, the firm data are stacked very much like panel data analysis. The stacking procedure is explained in Vuolteenaho (2002). The series are winsorized to eliminate extreme observations and possible misreports, following Cleary (1999). For each firm, the variable data are formed into a column. Then three lags of the variable are formed as three new columns. This is repeated for each firm and as a result, the first column has the original data of the firms stacked on top of each other. The other columns represent the first, second, and third lag. For winsorization, the observations of the first column are ranked from highest to lowest and the top (bottom) 1 percent of the values are redefined to be equal to the value just below (above) them.

Because observations from different firms and years in each country are stacked, one potential complication is year effects. To control for possible business cycle effects, dummy variables for each year are introduced as additional explanatory variables and additional regressions are conducted to test for robustness as discussed below.

\subsection{Financial Development Classifications}

In order to address the main theme of this study, the countries are classified based on the level of their financial development. Financial development has been the subject of several previous studies and indicators have been developed to measure the level of financial development in a country. Two such indicators are utilized.

The first index is based on Love (2003). The financial development index value of a country is the sum of two components. The first component is the stock market development index from Demirguc-Kunt and Levine (1996) and is equal to the sum of (standardized indices of) market capitalization of GDP, total value traded to GDP, and turnover (total value traded to market capitalization). The second component is the financial intermediary development index from Demirguc-Kunt and Levine (1996), which is equal to the sum of (standardized indices of) the ratio of liquid liabilities to the GDP and the ratio of domestic credit to private sector to the GDP.

The second index is based on a more recent study by Khurana et al. (2006) - KMP. This index is an average of the five standardized indices obtainable from the World Bank database: (1) market capitalization to the GDP ratio, (2) total value traded to the GDP ratio, (3) total value traded to market capitalization ratio, (4) the ratio of liquid liabilities to the GDP, and (5) the credit going to the private sector over the GDP ratio. The sum of the first three indices serves as a measure of stock market development. The sum of the last two indices reflects financial intermediary development. KMP is the sum of stock market development and financial intermediary development.

A higher value of financial development indicates that a country's financial systems relies relatively more on market-oriented financing and financial intermediaries. Table 1 reports the list of countries used in this study, the number of observations for each country and whether the country is classified as financially developed or not according to Love (2003) and Khurana et al. (2006) median values (the actual index values are given in each respective study). Using the financial development index values, the countries are ranked and separated into three groups of financially developed, middle, and not developed by the $33^{\text {rd }}$ and $66^{\text {th }}$ percentiles; and into five groups using the $20^{\text {th }}, 40^{\text {th }}, 60^{\text {th }}$, and $80^{\text {th }}$ percentiles to extract more specific information. Tests are applied to each financial development group.

\footnotetext{
${ }^{1}$ Formal tests for unit roots were conducted for the times series data. Neither the normalized earnings and capital spending, nor the returns series contain any unit roots.
} 


\subsection{Empirical Methodology}

Considering Akaike information, Schwarz information, Final Prediction error, and Hannan-Quinn criteria, three lags of the explanatory variables are used throughout to explain the exogenous variable. Causality tests are conducted for stock returns vs. earnings and capital spending instead of the standard regression tests. This way, earnings (capital spending) impact on the stock return is independently examined and multi-collinearity complications are avoided. The same types of tests are also used to examine the causality effect from capital spending to earnings and from earnings to capital investment. Two hypotheses tests are conducted:

$\mathrm{H}_{10}$ : $\quad$ Each lagged coefficient is jointly zero (causality test), and

$\mathrm{H}_{20}$ : The sum of lagged coefficients is zero (net cumulative effect test) combined with the sign of the net effect.

The first hypothesis tests whether all the lag coefficients of earnings (capital spending) are jointly zero in explaining stock returns. If statistically these coefficients are zero then there is no causality effect from earnings (capital spending) to stock returns. The second hypothesis tests whether the sum of the lag coefficients of earnings (capital spending) is statistically zero. If the sum is statistically zero, then the cumulative effect of earnings (capital spending) on annual returns is statistically insignificant. The same tests are applied for capital spending to earnings causality and for earnings to capital investment causality as well.

\section{Empirical Results And Discussion}

\subsection{Earnings And Capital Spending Causality On Returns}

The impact of earnings and capital spending on annual stock returns is examined with

$$
R_{t}=\alpha_{r}+\sum_{i=1}^{i=3} \beta_{i, r} E_{t-i}+\sum_{j=1}^{j=3} \gamma_{j, r} C_{t-j}+\sum_{k=1}^{k=3} \zeta_{k, r} R_{t-k}+\varepsilon_{r, t}
$$

where $C_{t}$ is formally defined as capital spending in year $t$ divided by total assets in year $t$, and $E_{t}$ stands for earnings in year $t$ divided by total assets in year $t$, and $R_{t}$ stands for the return in year $t$. Three lags of the explanatory variables are used as explained above. hypotheses:

Causality of the earnings and capital spending on stock returns is formally tested with two alternative

$\mathrm{H}_{\mathrm{e} 10}$ : Earnings do not granger-cause stock returns. If the coefficients of earnings lags are not all jointly zero statistically, then the hypothesis is rejected, which means earnings influence future dividends, which in turn influence subsequent stock returns. Therefore, earnings granger-cause subsequent stock returns.

$\mathrm{H}_{\mathrm{e} 20}$ : The net cumulative effect of earnings on subsequent stock returns is statistically zero. If the sum of the coefficients of earnings lags is not statistically equal to zero in explaining future stock returns, then the hypothesis is rejected and earnings increase leads to future returns.

These two hypothesis test results are reported in Table 2 and Table 3 as Test 1 and Test 2 results. In a similar manner, causality of capital spending on stock returns is formally tested with two alternative hypotheses:

$\mathrm{H}_{\mathrm{c} 10}$ : Capital spending does not granger-cause future stock returns. If the coefficients of capital spending lags are not all jointly zero statistically, then the hypothesis is rejected, which means capital spending influences future earnings and indirectly future dividends; which in turn influence returns. Therefore, capital spending grangercauses returns. 
$\mathrm{H}_{\mathrm{c20}}$ : The net cumulative effect of capital spending on stock returns is zero. If the sum of the coefficients of capital spending lags is not statistically equal to zero in explaining returns, then the hypothesis is rejected and an increase in capital spending leads to stock returns. These two hypothesis tests are reported in Table 2 and Table 3 as Test 3 and Test 4.

Table 2 reports the regression results for financial development classifications based on Love (2003). The countries are divided into three and into five different financial development groups. The two pairs of test results of earnings and capital expense impacts on subsequent returns are not clear for the three group categorization. However, when the classification is finer with five financial development groups, interesting results emerge. For the non-financial group, earnings do not impact stock returns neither according to Test1 nor according to Test 2 . Lags of earnings coefficients jointly do not impact returns. Earnings coefficients cumulatively do not impact subsequent earnings either. Furthermore, capital spending does not impact future returns either, jointly or cumulatively. Both Test 3 and Test 4 are insignificant and reveal that capital spending does not explain stock returns. On the other hand, when we examine the financially developed group, we see that both earnings and capital spending impact stock returns according to all four tests. The lags of earnings and the lags of capital spending jointly and cumulatively influence stock returns.

\subsection{Business Cycle Effects With Year Dummies}

Because the sample is created by stacking observations from different firms, years, and countries, one potential complication when we use the data is year effects. To control for possible business cycle effects, dummy variables are introduced for each year as additional explanatory variables. This fixed effects regression is

$R_{t}=\alpha_{r}+\sum_{i=1}^{i=3} \beta_{i, r} E_{t-i}+\sum_{j=1}^{j=3} \gamma_{j, r} C_{t-j}+\sum_{k=1}^{k=3} \zeta_{k, r} R_{t-k}+D_{2004}+\ldots+D_{1994}+\varepsilon_{r 1, t}$

where $D_{i}$ is ' 1 ' if the observation is in year $i$ and ' 0 ' if the observation is not in year $i$. Three lags of earnings, capital spending, and returns are used to explain annual returns. The regression results are reported in the second part of Table 2 for the Love (2003) financial development classifications. While the three-group classification does not reveal much insight, the five-group finer classification provides similar evidence as before. The non-financially developed group regressions indicate that neither earnings nor capital spending Granger causes future stock returns. But for financially developed country group, both earnings and capital spending Granger cause stock returns. The earnings lag coefficients jointly and cumulatively impact stock returns. So do the lags of capital spending coefficients, jointly and cumulatively.

Table 3 examines the same issue using the financial development classification according to the more recent study by Khurana et al. (2006). The rough classification of three financial development groups is followed by the more detailed classification of five financial development groups. As in Table 2, earnings and capital spending influence future stock returns in financially developed countries but not in financially non-developed countries, both according to the original tests and according to the tests with year dummies.

These results can be interpreted in several different ways. First, financially developed countries make it easy for firms to get external financing. Capital spending in these countries, whether originating externally or internally, influences stock returns significantly. Furthermore, earnings in financially developed countries also lead to significant stock returns. It seems that well-functioning financial markets also bring in the monitoring mechanisms and efficient corporate governance structures. The managers in financially developed countries use earnings and capital spending on projects and investments that influence stock returns. We do not see these in financially non-developed countries.

Finally Figure 1 demonstrates how the adjusted R-square values change for different financial development regressions. The stock return regressions have higher adjusted R-square values in financially non-developed countries both according to Love (2003) and Khurana et al. (2006) classifications. The conclusion holds both for groups of three and five financial development classifications. The high adjusted R-square values imply that past 
returns, earnings, and capital spending explain a greater portion of future stock returns in financially non-developed countries. This indicates potential inefficiencies in these countries. On the other hand, in financially developed countries, markets are efficient and therefore, the adjusted R-square values are lower; past returns, earnings, and capital spending explain a smaller portion of future stock returns.

\subsection{Causality From Capital Spending To Earnings}

Next we examine whether causality from capital spending to future earnings is different in financially developed countries and financially non-developed countries. This analysis will help to find out whether capital spending increases earnings or not. The expectation is that in financially developed countries capital spending will lead to fruitful investments and earnings will increase. In financially non-developed countries, this is an open empirical question. The following regressions are used for the causality tests:

$$
E_{t}=\alpha_{e}+\sum_{i=1}^{i=3} \beta_{i, e} E_{t-i}+\sum_{j=1}^{j=3} \gamma_{j, e} C_{t-j}+\varepsilon_{e, t}
$$

where earnings is the dependent variable and capital spending lags are explanatory variables along with earnings lags. The regressions answer whether an increase in capital expenditure leads to an increase in subsequent earnings.

Because we are stacking observations from different firms and years in each country, this might be an important issue in the analyses because unlike the prior studies on U.S. firms, some countries have data that cover relatively shorter periods of time. To control for possible business cycle effects, as before, dummy variables for each year are introduced as additional explanatory variables with

$$
E_{t}=\alpha_{e}+\sum_{i=1}^{i=3} \beta_{i, e} E_{t-i}+\sum_{j=1}^{j=3} \gamma_{j, e} C_{t-j}+D_{2004}+\ldots+D_{1994}+\varepsilon_{e, t}
$$

The goal is to see whether an increase in capital spending leads to an increase in earnings in the presence of year dummies. As before we address the issue with two formal hypotheses:

$\mathrm{H}_{\mathrm{c} 10}$ : Capital investments do not granger-cause earnings. Test 1 in Table 4 shows presents whether lags of capital investment estimates are jointly zero or not. If the hypothesis is not accepted, then investment decisions are value increasing and capital investments granger-cause earnings.

$\mathrm{H}_{\mathrm{c} 20}$ : The net cumulative effect of capital expenditure on earnings is not significantly positive. Test 2 answers whether the sum of the capital expenditure lags is statistically zero or not. If the hypothesis is not supported, that would mean that capital investment decisions lead to increases in earnings.

The capital expenditure coefficients from both tests in Table 4 indicate that in financially non-developed countries capital expenditure actually decreases future earnings. This is a surprising result. Apparently overall capital spending is not on projects with positive NPVs. The results are significant by at least one test at ten percent significance or better. The conclusions hold for regressions with year dummies and for both Love (2003) and Khurana et al. (2006) financial development classifications.

On the other hand, capital spending increases future earnings in financially developed countries. This is the most important difference compared to the financially non-developed country results. The cumulative impact of capital spending on different investments is positive future earnings. We also note that most statistical tests are not significant at conventional levels. This indicates that the impact of capital spending to earnings is relatively prompt. Earnings increase is contemporaneous indicating efficiency in financially developed economies. These results hold for regressions with year dummies, and for both Love (2003) and Khurana et al. (2006) financial development classifications. 


\subsection{Earnings To Capital Spending}

The impact of earnings on capital investment is investigated with the regression of the form

$C_{t}=\alpha_{c}+\sum_{i=1}^{i=3} \beta_{i, c} E_{t-i}+\sum_{j=1}^{j=3} \gamma_{j, c} C_{t-j}+\varepsilon_{c, t}$,

where three lags of earnings and capital expenditure are used to explain capital expenditure. To examine whether the results are influenced by business cycles, the impact of earnings on capital expenditure is examined further by including year dummies as additional explanatory variables with

$C_{t}=\alpha_{c}+\sum_{i=1}^{i=3} \beta_{i, c} E_{t-i}+\sum_{j=1}^{j=3} \gamma_{j, c} C_{t-j}+D_{2004}+\ldots+D_{1994}+\varepsilon_{c, t}$

Causality of the earnings to capital expenditure relationship is formally tested with two alternative hypotheses:

$\mathrm{H}_{\mathrm{e} 10}$ : Earnings do not granger-cause capital investments. If each coefficient of earnings lags are not all jointly zero statistically, then the hypothesis is rejected, which means earnings Granger-cause capital spending.

$\mathrm{H}_{\mathrm{e} 20}$ : The net cumulative effect of earnings on capital investments is not significantly positive. If the sum of the coefficients of earnings lags is not statistically equal to zero, then earnings increase leads to an increase in capital investment.

We report the results in Table 5. There is clear evidence that earnings Granger-cause capital investment. Earnings have a cumulative impact of increasing capital investment as well. There does not seem to be a difference in this regard between financially developed and undeveloped countries. And the results are consistent both for the Love (2003) index classification and the Khurana et al. (2006) index classification. The results from regressions using year dummies reaffirm the conclusions above.

\section{Conclusion}

This study investigates how financial development affects causality relationships from earnings and capital spending to stock returns and between earnings and capital spending. Neither earnings nor capital spending Granger causes stock returns for the financially non-developed group of countries. On the other hand, both earnings and capital spending Granger-cause stock returns in the financially developed group. Financially developed countries make it easy for firms to get external financing and capital spending in these countries, whether originating externally or internally, influences stock returns significantly.

There is weak evidence of Granger-causality from capital spending to earnings in financially undeveloped countries; however, the cumulative effect reduces earnings. In financially developed countries, on the other hand, the cumulative effect of capital spending to earnings is positive (though not very significant); in other words, capital investment does lead to increased earnings since the point estimates are positive. In financially developed countries, external financing is cheap and easy to obtain (Rajan and Zingales, 1998). Managers may prefer external funding and they are not faced with financing constraints. As a result, capital investment, which originates from internal resources, has inconsequential causality effect on earnings.

\section{Acknowledgements}

I would like to thank Bong Soo Lee, Shinichi Sakata, Nejat Seyhun, and Jungwon Suh for their suggestions and comments. 


\section{References}

1. Cleary, S., 1999, The relationship between firm investment and financial status, The Journal of Finance, 64, 673-692.

2. Demirguc-Kunt, A., and V. Maksimovic, 1998, Law, Finance and Firm Growth, Journal of Finance 53, 2107-2131.

3. Demirguc-Kunt, A., and R. Levine, 1996, Stock Market Development and Financial Intermediaries: Stylized Facts, World Bank Economic Review 10, 291-321.

4. $\quad$ Gomes, J., 2002, Financing Investment, American Economic Review 91, 1263-1285.

5. Khurana, I.K., Martin, X., and R. Pereira, 2006, Financial development and the cash flow sensitivity of cash, Journal of Financial and Quantitative Analysis, forthcoming.

6. La Porta, R., Lopez-de-Silanes, F., Shleifer, A., and R. Vishny, 1997, Legal Determinants of External Finance, Journal of Finance 52, 1131-1150.

7. Love, I., 2003, Financial development and financing constraints, The Review of Financial Studies, 16, 765791.

8. $\quad$ Rajan, R., and L. Zingales, 1998, Financial dependence and growth, American Economic Review 88, 559586.

9. Strong, N, and M. Walker, 1993, The explanatory power of earnings for stock returns, The Accounting Review, 68, 385-399.

10. Vuolteenaho, T., 2002, What drives firm-level stock returns?, Journal of Finance, 57, 233-264. 
Table 1. Descriptive Data on Each Country

\begin{tabular}{|c|c|c|c|c|}
\hline \multicolumn{2}{|c|}{ Country } & \multirow[t]{2}{*}{ Nobs } & \multicolumn{2}{|c|}{ Financial Development Index } \\
\hline & Code & & Love & 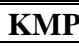 \\
\hline Germany & $\mathrm{DE}$ & 3391 & FD & FD \\
\hline France & FR & 2687 & FD & FD \\
\hline Italy & IT & 1211 & NFD & NFD \\
\hline Japan & $\mathrm{JP}$ & 8939 & FD & FD \\
\hline Australia & $\mathrm{AU}$ & 1729 & FD & NFD \\
\hline Canada & $\mathrm{CA}$ & 2296 & FD & NFD \\
\hline UK & GB & 8426 & FD & FD \\
\hline US & US & 33185 & FD & FD \\
\hline Argentina & AR & 239 & NFD & NFD \\
\hline Austria & AT & 385 & FD & NFD \\
\hline Belgium & $\mathrm{BE}$ & 530 & NFD & FD \\
\hline Brazil & $\mathrm{BR}$ & 803 & NFD & NFD \\
\hline Switzerland & $\mathrm{CH}$ & 1265 & FD & FD \\
\hline Chile & $\mathrm{CL}$ & 759 & NFD & NFD \\
\hline China & $\mathrm{CN}$ & 1866 & - & - \\
\hline Colombia & $\mathrm{CO}$ & 167 & NFD & NFD \\
\hline Denmark & DK & 952 & NFD & NFD \\
\hline Spain & ES & 858 & FD & FD \\
\hline Finland & FI & 698 & NFD & FD \\
\hline Greece & GR & 42 & - & - \\
\hline Indonesia & ID & 1226 & NFD & NFD \\
\hline Korea & $\mathrm{KR}$ & 1195 & $\mathrm{FD}$ & FD \\
\hline Mexico & MX & 550 & NFD & NFD \\
\hline Holland & NL & 911 & FD & FD \\
\hline Norway & NO & 741 & FD & NFD \\
\hline Philippines & PH & 672 & NFD & NFD \\
\hline Portugal & $\mathrm{PT}$ & 237 & NFD & FD \\
\hline Sweden & SE & 1226 & NFD & FD \\
\hline Turkey & TR & 400 & NFD & FD \\
\hline Taiwan & TW & 1702 & - & - \\
\hline Hong Kong & HK & 2645 & - & - \\
\hline Ireland & IE & 321 & - & - \\
\hline Israel & IL & 212 & FD & - \\
\hline India & IN & 1501 & NFD & NFD \\
\hline Malaysia & MY & 2930 & FD & FD \\
\hline New Zealand & $\mathrm{NZ}$ & 300 & NFD & NFD \\
\hline Pakistan & PK & 386 & NFD & FD \\
\hline Singapore & SG & 1478 & FD & FD \\
\hline Thailand & $\mathrm{TH}$ & 1820 & FD & FD \\
\hline South Africa & $\mathrm{ZA}$ & 845 & FD & FD \\
\hline
\end{tabular}

Nobs: Number of Observations. For both the Love (2003) and Khurana et al. (2006) classifications, the median of the index is used to determine whether the country is financially developed (FD) or not (NFD). 
Table 2. Love (2003) Financial Development, Returns, Earnings, and Capital Spending

\begin{tabular}{|c|c|c|c|c|c|c|c|c|c|c|c|c|c|c|}
\hline LOVE (2003) & Int. & $\mathbf{E}_{\mathrm{t}-1}$ & $\mathbf{E}_{\mathrm{t}-2}$ & $\mathbf{E}_{\mathrm{t}-3}$ & $\mathrm{C}_{\mathrm{t}-1}$ & $\mathrm{C}_{\mathrm{t}-2}$ & $\mathrm{C}_{\mathrm{t}-3}$ & $\mathbf{R}_{t-1}$ & $\mathbf{R}_{\mathrm{t}-2}$ & $\mathbf{R}_{\mathbf{t}-3}$ & Test1 & Test2 & Test3 & Test4 \\
\hline Not FD & $0.42^{* * * *}$ & $-1.29^{* * * *}$ & -0.59 & 0.66 & -0.59 & -1.26 & 0.33 & $0.32^{* * * *}$ & $0.05^{* * *}$ & $-0.03^{* * * *}$ & 0.00 & 0.01 & 0.14 & 0.05 \\
\hline Mid & $0.20^{* * * *}$ & $0.23^{* * *}$ & -0.09 & $-0.18^{* * * *}$ & -0.06 & 0.05 & 0.12 & -0.01 & $-0.11^{\text {**** }}$ & $-0.05^{* * *}$ & 0.00 & 0.58 & 0.50 & 0.32 \\
\hline FD & $0.20^{* * * *}$ & $0.07^{* * *}$ & $-0.20^{* * * *}$ & $-0.05^{* * *}$ & $-0.32^{* * * *}$ & $0.45^{* * *}$ & -0.08 & $-0.09^{* * *}$ & $-0.05^{* * * *}$ & $-0.09^{* * * *}$ & 0.00 & 0.00 & 0.00 & 0.35 \\
\hline Not FD & $0.60^{* * * * \pi}$ & $-1.37^{* * 4}$ & -0.33 & 0.88 & -0.58 & $-3.11^{*}$ & 1.79 & $0.32^{* * \cdots+}$ & $0.05^{* * * *}$ & $-0.04^{* * * *}$ & 0.13 & 0.29 & 0.23 & 0.25 \\
\hline Mid2 & $0.17^{* * * *}$ & $0.94^{* * *}$ & $-0.79^{* * * *}$ & 0.14 & -0.27 & 0.06 & $-0.41^{* *}$ & 0.02 & -0.02 & $-0.09^{* * * *}$ & 0.00 & 0.07 & 0.00 & 0.00 \\
\hline Mid3 & $0.24^{* * * *}$ & $0.35^{* * *}$ & -0.03 & $-0.25^{* * *}$ & 0.05 & -0.24 & -0.06 & $-0.04^{* * * *}$ & $-0.12^{\text {**** }}$ & -0.02 & 0.00 & 0.40 & 0.28 & 0.12 \\
\hline Mid4 & $0.24^{* * * *}$ & $0.22^{* * * *}$ & $-0.19^{* * * *}$ & $-0.22^{* * *}$ & -0.18 & -0.03 & 0.04 & $0.01^{* *}$ & $-0.10^{* * * *}$ & $-0.06^{* * * *}$ & 0.00 & 0.00 & 0.46 & 0.18 \\
\hline \multicolumn{15}{|c|}{ LOVE (2003) w/Year } \\
\hline Not FD & 9.98 & $-1.02^{* * * * *}$ & -0.53 & 0.23 & -1.15 & $\begin{array}{l}-0.98 \\
\end{array}$ & 0.44 & $0.29^{* * * * * *}$ & $0.05^{* 2 * 3}$ & $-0.03^{* * * * *}$ & 0.00 & 0.00 & 0.05 & 0.02 \\
\hline Mid & $0.47^{* * * *}$ & $0.20^{* * * *}$ & -0.06 & $-0.17^{* * *}$ & -0.13 & 0.10 & $0.22^{* *}$ & 0.01 & $-0.08^{* * * *}$ & $-0.05^{* * * *}$ & 0.00 & 0.57 & 0.02 & 0.05 \\
\hline FD & $0.32^{* * * *}$ & $0.05^{* * * *}$ & $-0.18^{* * *}$ & $-0.05^{* * *}$ & $-0.27^{* * *}$ & $0.41^{* * * *}$ & -0.03 & $-0.07^{* * *}$ & $-0.05^{* * *}$ & $-0.08^{* * *}$ & 0.00 & 0.00 & 0.00 & 0.06 \\
\hline Not FD & $26.27^{* * *}$ & -0.34 & -0.31 & -0.25 & 0.16 & $-2.35^{*}$ & 1.22 & $0.21^{* * * *}$ & $0.04^{* * * *}$ & -0.02 & 0.48 & 0.12 & 0.31 & 0.43 \\
\hline Mid2 & $0.36^{* * * *}$ & $0.95^{* * * *}$ & $-0.79^{* * * *}$ & 0.07 & -0.31 & 0.06 & $-0.32^{* *}$ & 0.02 & 0.02 & $-0.09^{* * * *}$ & 0.00 & 0.15 & 0.01 & 0.00 \\
\hline Mid3 & $0.67^{* * * *}$ & $0.25^{* * * *}$ & 0.06 & $-0.17^{* *}$ & 0.03 & -0.20 & 0.07 & -0.02 & $-0.08^{* * * *}$ & -0.02 & 0.00 & 0.12 & 0.60 & 0.50 \\
\hline Mid4 & $0.40^{* * * *}$ & $0.25^{* * * *}$ & $-0.14^{* * *}$ & $-0.23^{* * * *}$ & -0.15 & -0.06 & 0.08 & 0.02 & $-0.09^{* * * *}$ & $-0.06^{* * * *}$ & 0.00 & 0.05 & 0.51 & 0.25 \\
\hline
\end{tabular}

Three lags of earnings, capital spending, and returns are used to explain returns for financial developed and non-developed countries pooled together. Financial development classification are done following Love (2003). Panel A reports the original regressions and Panel B reports regressions with year dummies. The countries are categorized into three groups: non-financially developed, middle, and financially developed groups. This is followed by the categorization into five groups: non-financially developed, three middle, and financially developed groups. ${ }^{* * *},{ }^{* *},{ }^{*}$ represent $1 \%, 5 \%$, and $10 \%$ significance levels. Test 1 (Test 3 ) is about whether Earnings (Cap. Spending) coefficients are jointly zero. Test 2 (Test 4) is about whether the cumulative sum is zero. P-values are reported for all tests. 
Table 3. KMP (2006) Financial Development, Returns, Earnings, and Capital Spending

\begin{tabular}{|c|c|c|c|c|c|c|c|c|c|c|c|c|c|c|}
\hline KMP (2006) & Int. & $E_{t-1}$ & $E_{t-2}$ & $E_{t-3}$ & $\mathrm{C}_{\mathrm{t}-1}$ & $\mathrm{C}_{\mathrm{t}-2}$ & $\mathrm{C}_{\mathrm{t}-3}$ & $\mathrm{R}_{\mathrm{t}-1}$ & $\mathrm{R}_{\mathrm{t}-2}$ & $\mathrm{R}_{\mathrm{t}-3}$ & Test1 & Test2 & Test3 & Test 4 \\
\hline Not FD & $0.42^{* * *}$ & $-1.12^{\text {**a* }}$ & -0.32 & 0.40 & -0.50 & -1.58 & 0.72 & $0.32^{* * m}$ & $0.05^{* * * *}$ & $-0.03^{\text {N***F }}$ & 0.02 & 0.03 & 0.23 & 0.15 \\
\hline Mid & $0.22^{* * * *}$ & $0.29^{* * * *}$ & $-0.19^{* * * *}$ & $-0.21^{* * * *}$ & -0.16 & 0.03 & -0.12 & $-0.02^{* *}$ & $-.10^{* * * *}$ & $-0.07^{* * * *}$ & 0.00 & 0.05 & 0.06 & 0.01 \\
\hline FD & $0.19^{* * * *}$ & $0.06^{* * *}$ & $-0.20^{* * * *}$ & $-0.05^{* * * *}$ & $-0.34^{* * *}$ & $0.47^{* * * *}$ & -0.04 & $-0.09^{* * * *}$ & $-.05^{* * *}$ & $-0.09^{* * * *}$ & 0.00 & 0.00 & 0.00 & 0.09 \\
\hline Not FD & $0.53^{* * *}$ & $-1.37^{* * *}$ & -0.41 & 0.81 & -0.38 & $-2.96^{*}$ & 1.82 & $0.32^{* * * *}$ & $0.05^{* * * *}$ & $-0.04^{* * * *}$ & 0.09 & 0.20 & 0.26 & 0.34 \\
\hline Mid2 & $0.22^{* * *}$ & 0.16 & -0.04 & -0.20 & $-0.44^{* *}$ & 0.03 & $-0.38^{* *}$ & 0.00 & $-.05^{* * *}$ & $-0.03^{* *}$ & 0.23 & 0.54 & 0.00 & 0.00 \\
\hline Mid3 & $0.23^{* * *}$ & $0.27^{* * * *}$ & $-0.18^{* * *}$ & $-0.23^{* * *}$ & -0.09 & -0.05 & 0.01 & 0.01 & $-.10^{* * * *}$ & $-0.06^{* * * *}$ & 0.00 & 0.02 & 0.70 & 0.25 \\
\hline Mid4 & $0.17^{* * *}$ & 0.12 & -0.05 & 0.13 & $0.24^{*}$ & 0.18 & $-0.27^{* *}$ & $-0.16^{* * *}$ & $-.15^{* * *}$ & $-0.03^{* * *}$ & 0.08 & 0.02 & 0.02 & 0.25 \\
\hline FD & $0.19^{* * * *}$ & $0.06^{* * *}$ & $-0.20^{* * * *}$ & $-0.04^{* * *}$ & $-0.50^{* * *}$ & $0.58^{* * * *}$ & 0.02 & $-0.09^{* * *}$ & $-.04^{* * * *}$ & $-0.10^{* * * *}$ & 0.00 & 0.00 & 0.00 & 0.11 \\
\hline KMP (2006) w/Year & Int. & $\mathrm{E}_{\mathrm{t}-1}$ & $\mathrm{E}_{\mathrm{t}-2}$ & $E_{t-3}$ & $\mathrm{C}_{\mathrm{t}-1}$ & $\mathrm{C}_{\mathrm{t}-2}$ & $\mathrm{C}_{\mathrm{t}-3}$ & $R_{t-1}$ & $\mathrm{R}_{\mathrm{t}-2}$ & $\mathrm{R}_{\mathrm{t}-3}$ & Test1 & Test2 & Test3 & Test4 \\
\hline Not FD & $8.46^{* * * *}$ & $-0.75^{* *}$ & -0.29 & 0.04 & -0.29 & -2.07 & 0.15 & $0.30^{* * 4}$ & $0.05^{* * * 4 *}$ & $-0.03^{\text {*⿻丷木 }}$ & 0.07 & 0.02 & 0.03 & 0.01 \\
\hline Mid & $0.44^{* * * *}$ & $0.32^{* * * *}$ & $-0.14^{* * * *}$ & $-0.23^{* * *}$ & -0.16 & 0.01 & -0.06 & -0.01 & $-.07^{* * * *}$ & $-0.06^{* * *}$ & 0.00 & 0.32 & 0.14 & 0.02 \\
\hline FD & $0.32^{* * * *}$ & $0.04^{* * * *}$ & $-0.18^{\text {**** }}$ & $-0.05^{* * * *}$ & $-0.31^{* * *}$ & $0.44^{* * * *}$ & 0.01 & $-0.07^{* * * *}$ & $-.05^{* * * *}$ & $-0.08^{* * * *}$ & 0.00 & 0.00 & 0.00 & 0.01 \\
\hline Not FD & $9.04^{* * * *}$ & -0.64 & -0.59 & -0.04 & -1.09 & $-2.49^{*}$ & 1.88 & $0.25^{* * * * \pi}$ & $0.05^{* * *}$ & $-0.02^{* *}$ & 0.17 & 0.04 & 0.11 & 0.20 \\
\hline Mid2 & $0.58^{* * * *}$ & 0.14 & 0.05 & -0.15 & $-0.30^{*}$ & 0.03 & $-0.34^{* *}$ & 0.01 & -0.02 & $-0.05^{* * * *}$ & 0.42 & 0.82 & 0.00 & 0.00 \\
\hline Mid3 & $0.42^{* * * *}$ & $0.30^{* * * *}$ & $-0.12^{* *}$ & $-0.26^{* * * *}$ & -0.11 & -0.07 & 0.06 & $0.03^{* *}$ & $-.09^{* * * *}$ & $-0.05^{* * * *}$ & 0.00 & 0.16 & 0.62 & 0.29 \\
\hline Mid4 & $0.51^{* * * * *}$ & $0.15^{* *}$ & -0.01 & 0.05 & $0.22^{*}$ & 0.09 & $-0.23^{* * *}$ & $-0.13^{* * *}$ & $-.09^{* * * *}$ & $-0.03^{* * * *}$ & 0.07 & 0.03 & 0.07 & 0.55 \\
\hline
\end{tabular}

Three lags of earnings, capital spending, and returns are used to explain returns for financial developed and non-developed countries pooled together. Financial development classification are done following KMP (2006). Panel A reports the original regressions and Panel B reports regressions with year dummies. The countries are categorized into three groups: non-financially developed, middle, and financially developed groups. This is followed by the categorization into five groups: non-financially developed, three middle, and financially developed groups. ${ }^{* * *},{ }^{* *},{ }^{*}$ represent $1 \%, 5 \%$, and $10 \%$ significance levels. Test 1 (Test 3 ) is about whether Earnings (Cap. Spending) coefficients are jointly zero. Test 2 (Test 4 ) is about whether the cumulative sum is zero. P-values are reported for all tests. 
Table 4. Financial Development, Earnings vs. Capital Spending Lags

\begin{tabular}{|c|c|c|c|c|c|c|c|c|c|}
\hline Panel A. Love (2003) & Int. & $\mathrm{E}_{\mathrm{t}-1}$ & $\mathrm{E}_{\mathrm{t}-2}$ & $\mathrm{E}_{\mathrm{t}-3}$ & $\mathrm{C}_{\mathrm{t}-1}$ & $\mathrm{C}_{\mathrm{t}-2}$ & $\mathrm{C}_{\mathrm{t}-3}$ & Test1 & Test2 \\
\hline Not FD & $0.01^{* * * * *}$ & $0.40^{* * * * *}$ & $0.22^{* * * * * 2}$ & $0.08^{* * * 2}$ & -0.01 & 0.00 & -0.03 & 0.12 & 0.02 \\
\hline Mid & 0.00 & $0.50^{* * * *}$ & $0.08^{* * *}$ & $0.16^{* * *}$ & -0.02 & $0.06^{* *}$ & -0.03 & 0.12 & 0.67 \\
\hline FD & $-0.01^{* * * *}$ & $0.48^{* * * *}$ & $0.15^{* * *}$ & $0.15^{* * *}$ & -0.03 & 0.03 & 0.01 & 0.30 & 0.38 \\
\hline Not FD & $0.01^{*}$ & $0.35^{* * * *}$ & $0.21^{* * * *}$ & $0.07^{* * * *}$ & -0.02 & 0.00 & -0.05 & 0.18 & 0.05 \\
\hline Mid2 & $0.00^{* * * *}$ & $0.58^{* * * *}$ & $0.13^{* * * *}$ & $0.09^{* * *}$ & 0.00 & -0.01 & 0.00 & 0.93 & 0.57 \\
\hline Mid3 & 0.00 & $0.45^{* * *}$ & $0.10^{* * * *}$ & $0.10^{* * * *}$ & 0.01 & 0.04 & 0.00 & 0.28 & 0.09 \\
\hline Mid4 & 0.00 & $0.40^{* * * *}$ & $0.12^{* * *}$ & $0.20^{* * *}$ & -0.01 & 0.02 & -0.01 & 0.88 & 0.94 \\
\hline FD & $-0.01^{* * * *}$ & $0.49^{* * * *}$ & $0.15^{* * *}$ & $0.15^{* * *}$ & -0.03 & 0.04 & 0.01 & 0.28 & 0.47 \\
\hline Love (2003) w/Year & Int. & $\mathrm{E}_{\mathrm{t}-1}$ & $\mathrm{E}_{\mathrm{t}-2}$ & $\mathrm{E}_{\mathrm{t}-3}$ & $\mathrm{C}_{\mathrm{t}-1}$ & $\mathrm{C}_{\mathrm{t}-2}$ & $\mathrm{C}_{\mathrm{t}-3}$ & Test1 & Test2 \\
\hline Not FD & $0.02^{* * *}$ & $0.40^{* * 3 *}$ & $0.22^{* * * * *}$ & $0.08^{* * * *}$ & -0.01 & 0.00 & -0.03 & 0.32 & 0.11 \\
\hline Mid & 0.01 & $0.50^{* * * *}$ & $0.08^{* * * *}$ & $0.16^{* * *}$ & -0.02 & $0.06^{* *}$ & -0.02 & 0.09 & 0.33 \\
\hline FD & 0.00 & $0.48^{* * * *}$ & $0.15^{* * *}$ & $0.15^{* * *}$ & -0.03 & 0.02 & 0.02 & 0.30 & 0.62 \\
\hline Not FD & $0.03^{*}$ & $0.35^{* * *}$ & $0.21^{* * * *}$ & $0.08^{* * * *}$ & -0.01 & 0.00 & -0.04 & 0.42 & 0.16 \\
\hline Mid2 & 0.01 & $0.58^{* * * *}$ & $0.14^{* * *}$ & $0.09^{* * * *}$ & 0.00 & -0.01 & 0.00 & 0.87 & 0.40 \\
\hline Mid3 & 0.01 & $0.43^{* * * *}$ & $0.11^{* * * *}$ & $0.10^{* * * *}$ & 0.00 & 0.05 & 0.01 & 0.13 & 0.03 \\
\hline Mid4 & 0.00 & $0.40^{* * * *}$ & $0.13^{* * *}$ & $0.19^{* * *}$ & -0.01 & 0.03 & -0.01 & 0.85 & 0.93 \\
\hline FD & 0.00 & $0.48^{* * * *}$ & $0.15^{* * *}$ & $0.14^{* * *}$ & $-0.04^{*}$ & 0.03 & 0.02 & 0.25 & 0.68 \\
\hline Panel B. KMP (2006) & Int. & $\mathrm{E}_{\mathrm{t}-1}$ & $\mathrm{E}_{\mathrm{t}-2}$ & $\mathrm{E}_{\mathrm{t}-3}$ & $\mathrm{C}_{\mathrm{t}-1}$ & $\mathrm{C}_{\mathrm{t}-2}$ & $\mathrm{C}_{\mathrm{t}-3}$ & Test1 & Test2 \\
\hline Not FD & $0.00^{*}$ & $0.35^{* * *}$ & $0.18^{* * * *}$ & $0.10^{* * * * *}$ & $-0.07^{* * 6}$ & $0.07^{* * *}$ & -0.04 & 0.03 & 0.27 \\
\hline Mid & 0.00 & $0.42^{* * * *}$ & $0.12^{* * *}$ & $0.18^{* * *}$ & 0.01 & 0.01 & -0.01 & 0.94 & 0.78 \\
\hline FD & $-0.01^{* * * *}$ & $0.49^{* * * *}$ & $0.15^{* * *}$ & $0.15^{* * *}$ & -0.03 & 0.04 & 0.01 & 0.32 & 0.36 \\
\hline Not FD & 0.00 & $0.35^{* * * *}$ & $0.21^{* * * *}$ & $0.07^{* * * *}$ & -0.01 & 0.02 & -0.05 & 0.46 & 0.31 \\
\hline Mid2 & $0.01^{* * * *}$ & $0.43^{* * * *}$ & $0.11^{* * * *}$ & $0.15^{* * *}$ & $-0.06^{* *}$ & $0.04^{*}$ & -0.02 & 0.03 & 0.09 \\
\hline Mid3 & $0.00^{*}$ & $0.41^{* * * *}$ & $0.13^{* * * *}$ & $0.18^{* * *}$ & 0.01 & 0.01 & -0.01 & 0.80 & 0.41 \\
\hline Mid4 & 0.00 & $0.42^{* * * *}$ & $0.10^{* * *}$ & $0.18^{* * * *}$ & -0.02 & $0.07^{* * * *}$ & $-0.09^{* * *}$ & 0.00 & 0.08 \\
\hline FD & $-0.01^{* * * *}$ & $0.49^{* * * *}$ & $0.15^{\text {*** }}$ & $0.15^{* * * *}$ & -0.03 & 0.02 & 0.03 & 0.31 & 0.31 \\
\hline KMP (2006) w/Year & Int. & $\mathrm{E}_{\mathrm{t}-1}$ & $\mathrm{E}_{\mathrm{t}-2}$ & $\mathrm{E}_{\mathrm{t}-3}$ & $\mathrm{C}_{\mathrm{t}-1}$ & $\mathrm{C}_{\mathrm{t}-2}$ & $\mathrm{C}_{\mathrm{t}-3}$ & Test1 & Test2 \\
\hline Not FD & $0.02^{* * *}$ & $0.35^{* * *}$ & $0.18^{* * * *}$ & $0.10^{* * * *}$ & $-0.06^{*}$ & $0.06^{\text {*** }}$ & -0.03 & 0.08 & 0.27 \\
\hline Mid & 0.00 & $0.42^{* * * *}$ & $0.12^{* * * *}$ & $0.18^{* * * *}$ & 0.00 & 0.01 & -0.01 & 0.97 & 0.89 \\
\hline FD & 0.00 & $0.48^{* * * *}$ & $0.15^{* * * *}$ & $0.14^{* * *}$ & -0.04 & 0.03 & 0.02 & 0.26 & 0.48 \\
\hline Not FD & $0.02^{*}$ & $0.36^{* * *}$ & $0.20^{* * * *}$ & $0.08^{* * * *}$ & 0.00 & 0.01 & -0.04 & 0.66 & 0.51 \\
\hline Mid2 & $0.01^{*}$ & $0.42^{* * * *}$ & $0.11^{* * * *}$ & $0.15^{* * *}$ & $-0.07^{* * * *}$ & $0.04^{*}$ & -0.02 & 0.02 & 0.07 \\
\hline Mid3 & 0.00 & $0.41^{* * * *}$ & $0.13^{* * *}$ & $0.18^{* * *}$ & 0.01 & 0.02 & -0.01 & 0.77 & 0.40 \\
\hline Mid4 & $0.01^{*}$ & $0.41^{* * * *}$ & $0.11^{* * *}$ & $0.16^{* * *}$ & -0.03 & $0.06^{* * * *}$ & $-0.09^{* * *}$ & 0.00 & 0.01 \\
\hline FD & 0.00 & $0.48^{* * * *}$ & $0.15^{* * *}$ & $0.14^{* * * *}$ & -0.04 & 0.01 & $0.05^{*}$ & 0.15 & 0.32 \\
\hline
\end{tabular}

Three lags of earnings and capital spending are used to explain earnings for financial developed and non-developed countries pooled together. Love (2003) and KMP (2006) classifications are in Panel A and Panel B. ***, ** , ${ }^{*}$ represent 1\%, 5\%, and 10\% significance levels. Test 1 is about whether capital spending coefficients are jointly zero. Test 2 is about whether the cumulative sum of capital spending coefficients is zero. 
Table 5. Financial Development, Capital Spending vs. Earnings Lags

\begin{tabular}{|c|c|c|c|c|c|c|c|c|c|}
\hline Panel A. Love (2003) & Int. & $\mathrm{E}_{\mathrm{t}-1}$ & $\mathrm{E}_{\mathrm{t}-2}$ & $\mathrm{E}_{\mathrm{t}-3}$ & $\mathrm{C}_{\mathrm{t}-1}$ & $\mathrm{C}_{\mathrm{t}-2}$ & $\mathrm{C}_{\mathrm{t}-3}$ & Test1 & Test2 \\
\hline Not FD & $0.02^{* * * *}$ & 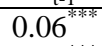 & $0.03^{* \text { *** }}$ & $-0.02^{* * * *}$ & $0.42^{* * * *}$ & $0.08^{* * * * 6}$ & 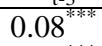 & 0.00 & 0.00 \\
\hline Mid & $0.01^{* * *}$ & $0.04^{* * *}$ & 0.00 & -0.01 & $0.44^{* * *}$ & $0.13^{* * * *}$ & $0.13^{* * * *}$ & 0.00 & 0.00 \\
\hline FD & $0.01^{* * * *}$ & $0.01^{* * * *}$ & $0.00^{* * * *}$ & 0.00 & $0.50^{* * * *}$ & $0.11^{* * * *}$ & $0.11^{* * * *}$ & 0.00 & 0.00 \\
\hline Not FD & $0.02^{* * * * *}$ & $0.05^{* * * *}$ & $0.03^{* * * * *}$ & $-0.01^{* *}$ & $0.44^{* * * *}$ & $0.07^{* * * * *}$ & $0.06^{* * * * *}$ & 0.00 & 0.00 \\
\hline Mid2 & $0.01^{* * *}$ & $0.10^{* * *}$ & 0.02 & $-0.04^{* * *}$ & $0.40^{* * *}$ & $0.09^{* * * *}$ & $0.11^{\text {**** }}$ & 0.00 & 0.00 \\
\hline Mid3 & $0.02^{* * *}$ & $0.03^{* * *}$ & 0.01 & 0.00 & $0.37^{* * *}$ & $0.14^{* * * *}$ & $0.10^{* * * *}$ & 0.00 & 0.00 \\
\hline Mid4 & $0.01^{* * * *}$ & $0.03^{* * * *}$ & $-0.01^{*}$ & $-0.01^{*}$ & $0.47^{* * *}$ & $0.13^{* * * *}$ & $0.10^{* * * *}$ & 0.00 & 0.00 \\
\hline FD & $0.01^{* * *}$ & $0.01^{* * *}$ & $0.00^{* * * *}$ & 0.00 & $0.50^{* * *}$ & $0.10^{* * *}$ & $0.12^{* * * *}$ & 0.00 & 0.00 \\
\hline Love (2003) w/Year & Int. & $\mathrm{E}_{\mathrm{t}-1}$ & $\mathrm{E}_{\mathrm{t}-2}$ & $\mathrm{E}_{\mathrm{t}-3}$ & $\mathrm{C}_{\mathrm{t}-1}$ & $\mathrm{C}_{\mathrm{t}-2}$ & $\mathrm{C}_{\mathrm{t}-3}$ & Test1 & Test2 \\
\hline Not FD & $0.02^{* * * *}$ & $0.05^{\text {**** }}$ & $0.02^{* * * *}$ & $-0.02^{* * * *}$ & $0.41^{* * * *}$ & $0.08^{2 * 3 *}$ & $0.08^{* 3 * * *}$ & 0.00 & 0.00 \\
\hline Mid & $0.01^{* * * *}$ & $0.03^{* * *}$ & 0.00 & 0.00 & $0.43^{* * * *}$ & $0.14^{* * * *}$ & $0.14^{* * * *}$ & 0.00 & 0.00 \\
\hline FD & $0.01^{* * * *}$ & $0.01^{* * * *}$ & $0.00^{* * * *}$ & $0.00^{*}$ & $0.49^{* * * *}$ & $0.11^{* * * *}$ & $0.11^{* * * *}$ & 0.00 & 0.00 \\
\hline Not FD & $0.03^{* * * *}$ & $0.04^{* * * *}$ & $0.02^{* * * *}$ & $-0.01^{*}$ & $0.43^{* * * *}$ & $0.07^{* 3 * *}$ & $0.06^{* * * *}$ & 0.00 & 0.00 \\
\hline Mid2 & $0.01^{* * *}$ & $0.09^{* * *}$ & 0.02 & $-0.03^{* *}$ & $0.40^{* * *}$ & $0.09^{* * * *}$ & $0.11^{* * * *}$ & 0.00 & 0.00 \\
\hline Mid3 & $0.01^{* * * *}$ & $0.03^{* * *}$ & 0.01 & 0.00 & $0.36^{* * *}$ & $0.14^{* * * *}$ & $0.11^{\text {**** }}$ & 0.00 & 0.00 \\
\hline Mid4 & $0.01^{* * *}$ & $0.03^{* * *}$ & $-0.01^{*}$ & $-0.01^{*}$ & $0.47^{* * *}$ & $0.13^{* * * *}$ & $0.10^{* * * *}$ & 0.00 & 0.00 \\
\hline FD & $0.01^{* * *}$ & $0.01^{* * * *}$ & $0.00^{* * * *}$ & 0.00 & $0.50^{* * * *}$ & $0.10^{* * *}$ & $0.12^{* * * *}$ & 0.00 & 0.00 \\
\hline Panel B. KMP (2006) & Int. & $\mathrm{E}_{\mathrm{t}-1}$ & $\mathrm{E}_{\mathrm{t}-2}$ & $\mathrm{E}_{\mathrm{t}-3}$ & $\mathrm{C}_{\mathrm{t}-1}$ & $\mathrm{C}_{\mathrm{t}-2}$ & $\mathrm{C}_{\mathrm{t}-3}$ & Test1 & Test2 \\
\hline Not FD & $0.02^{* * * * *}$ & $0.04^{* * * * * * 2}$ & $0.02^{* * * *}$ & -0.01 & $0.42^{* * * * * 6}$ & $0.11^{* * 3 *}$ & $0.08^{\text {***** }}$ & 0.00 & 0.00 \\
\hline Mid & $0.01^{* * *}$ & $0.03^{* * *}$ & 0.00 & $-0.01^{* *}$ & $0.44^{* * * *}$ & $0.12^{* * * *}$ & $0.11^{* * * *}$ & 0.00 & 0.00 \\
\hline FD & $0.01^{* * *}$ & $0.01^{* * * *}$ & $0.00^{* * * *}$ & 0.00 & $0.50^{* * * *}$ & $0.11^{* * * *}$ & $0.12^{* * * *}$ & 0.00 & 0.00 \\
\hline Not FD & $0.02^{* * * *}$ & $0.05^{* * * * *}$ & $0.02^{* * * *}$ & $-0.02^{* * *}$ & $0.44^{* * * *}$ & $0.07^{* * * *}$ & $0.06^{* * * *}$ & 0.00 & 0.00 \\
\hline Mid2 & $0.02^{* * * *}$ & $0.05^{\text {*** }}$ & 0.01 & 0.00 & $0.39^{* * *}$ & $0.10^{* * * *}$ & $0.09^{* * * *}$ & 0.00 & 0.00 \\
\hline Mid3 & $0.01^{* * * *}$ & $0.03^{\text {**** }}$ & -0.01 & $-0.01^{*}$ & $0.44^{* * *}$ & $0.15^{* * * *}$ & $0.12^{* * * *}$ & 0.00 & 0.00 \\
\hline Mid4 & $0.02^{* * *}$ & $0.03^{\text {**** }}$ & $0.02^{* * *}$ & 0.00 & $0.40^{* * *}$ & $0.11^{* * *}$ & $0.07^{* * *}$ & 0.00 & 0.00 \\
\hline FD & $0.01^{* * *}$ & $0.01^{* * *}$ & $0.00^{* * *}$ & 0.00 & $0.52^{* * *}$ & $0.09^{* * * *}$ & $0.13^{* * *}$ & 0.00 & 0.00 \\
\hline KMP (2006) w/Year & Int. & $\mathrm{E}_{\mathrm{t}-1}$ & $\mathrm{E}_{\mathrm{t}-2}$ & $\mathrm{E}_{\mathrm{t}-3}$ & $\mathrm{C}_{\mathrm{t}-1}$ & $\mathrm{C}_{\mathrm{t}-2}$ & $\mathrm{C}_{\mathrm{t}-3}$ & Test1 & Test2 \\
\hline Not FD & $0.03^{* * * * *}$ & $0.04^{* * * * *}$ & $0.02^{* * * *}$ & -0.01 & $0.41^{* * * *}$ & $0.12^{* * * *}$ & $0.07^{* * * * *}$ & 0.00 & 0.00 \\
\hline Mid & $0.01^{* * *}$ & $0.03^{* * *}$ & -0.01 & $-0.01^{*}$ & $0.44^{* * * *}$ & $0.12^{* * * *}$ & $0.12^{* * * *}$ & 0.00 & 0.00 \\
\hline FD & $0.01^{* * * *}$ & $0.01^{* * * *}$ & $0.00^{* * * *}$ & 0.00 & $0.50^{* * * *}$ & $0.11^{* * * *}$ & $0.12^{* * * *}$ & 0.00 & 0.00 \\
\hline Not FD & $0.03^{* * * *}$ & $0.05^{* * * *}$ & $0.02^{* * *}$ & $-0.02^{* * *}$ & 0.43 & 0.08 & $0.06^{\text {**** }}$ & 0.00 & 0.00 \\
\hline Mid2 & $0.02^{* * * *}$ & $0.04^{* * * *}$ & 0.01 & 0.01 & 0.38 & 0.10 & $0.10^{* * * *}$ & 0.00 & 0.00 \\
\hline Mid3 & $0.01^{* * * *}$ & $0.03^{\text {**** }}$ & $-0.01^{*}$ & $-0.01^{*}$ & 0.44 & 0.15 & $0.12^{\text {*** }}$ & 0.00 & 0.00 \\
\hline Mid4 & $0.02^{* * * *}$ & $0.03^{\text {**** }}$ & $0.02^{* * * *}$ & 0.00 & 0.39 & 0.11 & $0.07^{* * * *}$ & 0.00 & 0.00 \\
\hline FD & $0.01^{* * * *}$ & $0.01^{\text {**** }}$ & $0.00^{* * * *}$ & 0.00 & 0.52 & 0.09 & $0.13^{\text {*** }}$ & 0.00 & 0.00 \\
\hline
\end{tabular}

Three lags of earnings and capital spending are used to explain capital spending for financial developed and non-developed countries pooled together. Love (2003) and KMP (2006) classifications are in Panel A and Panel B. ${ }^{* * *},{ }^{* *},{ }^{*}$ represent $1 \%, 5 \%$, and $10 \%$ significance levels. Test 1 is about whether earnings coefficients are jointly zero. Test 2 is about whether the cumulative sum of earnings coefficients is zero. 

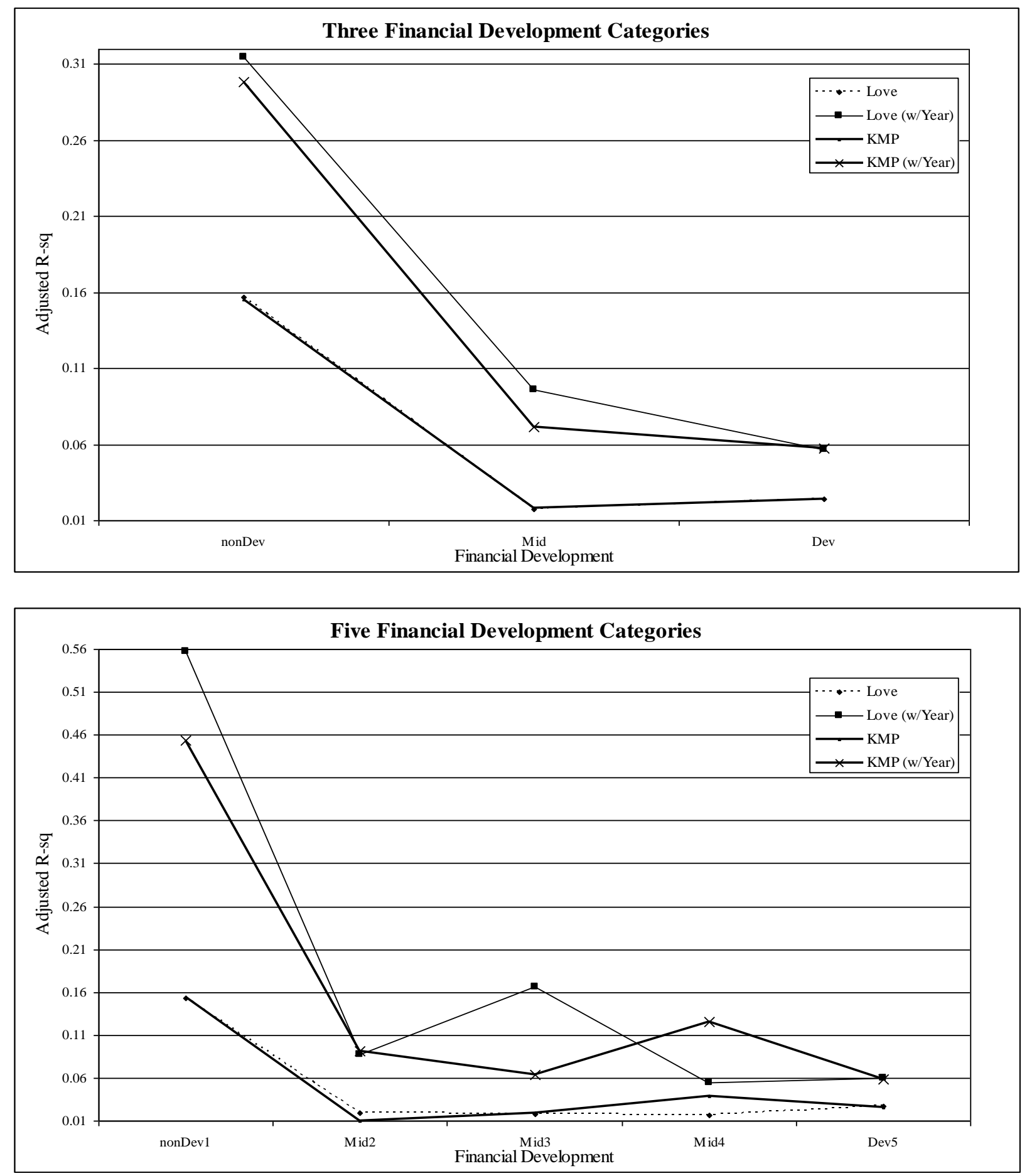

Figure 1. Adjusted R-square values of Return Regressions for Different Financial Development levels. 